$9-2001$

\title{
A Response to Hogan and Simpson
}

John P. Pelissero

Loyola University Chicago, jpeliss@luc.edu

Timothy B. Krebs

University of North Carolina at Greensboro

Follow this and additional works at: https://ecommons.luc.edu/politicalscience_facpubs

Part of the Political Science Commons

\section{Recommended Citation}

Pelissero, John P. and Timothy B. Krebs, "A Response to Hogan and Simpson," Urban Affairs Review Vol. 37 (September 2001): 96-99.

This Article is brought to you for free and open access by the Faculty Publications and Other Works by Department at Loyola eCommons. It has been accepted for inclusion in Political Science: Faculty Publications and Other Works by an authorized administrator of Loyola eCommons. For more information, please contact ecommons@luc.edu. (c) (1) $(9)$

This work is licensed under a Creative Commons Attribution-Noncommercial-No Derivative Works 3.0 License. 


\title{
A RESPONSE TO HOGAN AND SIMPSON
}

\author{
JOHN P. PELISSERO \\ Loyola University Chicago \\ TIMOTHY B. KREBS \\ University of North Carolina, Greensboro
}

The article by Hogan and Simpson provides another piece of the puzzle to explain campaign fund-raising coalitions in Chicago elections. We are pleased to see that their findings are consistent with our study. Although there are some differences in methodology between the two studies, our conclusions are similar: Richard M. Daley and Harold Washington had different bases to their campaign fund-raising coalitions, and this helped to produce different governing regimes.

How are the studies similar or different? The Hogan and Simpson article has two components - an examination of campaign fund-raising and a review of aldermanic support for mayors. Only the first aspect is relevant to the research that we have published here. In the second section, Hogan and Simpson attempt to link mayoral campaigns to what happens in the Chicago city council. Their article attempts also to link mayoral fund-raising to fundraising in aldermanic elections (Gierzynski, Kleppner, and Lewis 1996) and to support for mayors in city council roll call votes (Simpson 2001). Although we did not attempt to establish such a linkage in our research, the topic of aldermanic elections has been the subject of significant research by Krebs (e.g., 1998, 1999).

The clear difference in our studies is that whereas we examined campaign fund-raising from businesses, unions, political committees, and nonprofit organizations, they included individual contributors in their analysis. We had both practical and validity concerns that led us to limit the analysis to nonindividual contributors. Although both studies worked with campaign disclosure reports to classify the fund-raising into sectors, we found it impossible to consistently classify individuals correctly. For each of the five election cycles that was included in our study $(1983,1987,1989,1991,1995)$, 
2. Some further definitions are needed. The "construction" category includes both construction firms as well as the construction trade unions. The "political" category includes ward organizations, known party activists giving to individually elected officers, civil servants, and administrative appointees. The "financial" category includes' investment services such as banking, stock brokerage firms, the Chicago futures trading associations, real-estate brokers, and insurance companies. The "personnel" category includes temporary staff services, janitorial services, private security agencies, and rubbish removal businesses. The "tourism" category includes restaurants, taverns, airlines, taxi associations, casinos, and gifts from persons associated with such businesses.

The "civic" category includes gifts from churches and their preachers who contributed personally. This grouping also includes chambers of commerce, community organizations, and persons associated with activist groups such as Operation Push and the Urban League. Finally, the miscellaneous category included gifts from organizations, businesses, and groups that could not fit into the other categories. This would include individuals who identified themselves with a group that did not fit into a category.

\section{REFERENCES}

Gierzynski, A., P. Kleppner, and J. Lewis. 1996. The price of democracy: Financing Chicago's 1995 city elections. DeKalb: Northern Illinois Univ. Press.

Grimshaw, W. 1992. Bitter fruit: Black politics and the Chicago machine. Chicago: Univ. of Chicago Press.

Lewis, J., G. Taylor, and P. Kleppner. 1997. MetroChicago political atlas '97-'98. Chicago: Chicago Urban League, Metro Chicago Information Center, and Northern Illinois University.

Rast, J. 1999. Remaking Chicago: The political origins of urban industrial change. DeKalb: Northern Illinois Univ. Press.

Simpson, D. 2001. Rogues, rebels, and rubber stamps: The politics of the Chicago city council from 1863 to the present. Boulder, $\mathrm{CO}$ : Westview.

Sean Hogan is an assistant director of the Survey Research Office at the University of Illinois at Springfield. Recent publications include "Reconsidering the Effects of Partisan Loyalty on the Illinois Supreme Court," in Illinois Political Science Review. His dissertation, "Continuity and Change in the Common Law: The Illinois Supreme Court's Tort Policies 1971 to 1997," was approved recently in the Department of Political Science at the University of Illinois at Chicago.

Dick Simpson is a professor of political science at the University of Illinois at Chicago. He has more than 80 publications, including 16 books. His latest book is Rogues, Rebels, and Rubber Stamps: The Politics of the Chicago City Council from 1863 to the Present (Westview 200I). 
more than 5,000 entries-contributors - were listed for each candidate. Such entries include only names and addresses. Thus, for individuals, one would need to know each person and whether he or she represented a personal, business, or group interest when making a donation. A contribution from John Stroger of Chicago would be easily classified as a donation from a politician because it is widely known that Mr. Stroger is the president of the Cook County Board of Commissioners and the longtime Democratic leader of Chicago's 8th Ward organization. But another entry from John Smith of Chicago would not be so easily classified. Therefore, we focused on the nonindividual contributions that were more easily classified and more accurately placed in the right donor sector. We believe that this produced a set of categories that is more finely tuned to reflect the interests of campaign donors.

The results of including and classifying different contributors in our studies are not inconsequential. Hogan and Simpson report in Figures 1 and 4 the results of two elections, but with substantial "unidentified" contributors. It is difficult to make a reasonable comparison between Washington's contributors in 1987 (Figure 1) and Daley's 1999 contributors (Figure 4) because of the large component of unidentified contributors-67\% in 1987 and $25 \%$ in 1999. It appears from the figures that Washington received only $5.3 \%$ of funding from "building" interests, whereas Daley received three times that amount from the same interests in 1999. But the problem is that too much of the data in both figures are not identifiable because of the difficulty of classifying individuals when only name and address are available.

Another difference in the two studies is the time period examined. Hogan and Simpson use fewer elections and a shorter fund-raising period for each. Both studies looked at the 1983 election (Washington and Daley as primary competitors) and Washington's reelection in 1987. The subsequent elections are not similar. Whereas we examined the Daley election of 1989 and his reelections in 1991 and 1995, Hogan and Simpson look only at the most recent Daley reelection of 1999 . This produced some different results in the two studies. Comparing our Table 3 with their Figure 1 provides an example of the differences. Looking at a full year of fund-raising (July 1986 through June 1987), we show that $23 \%$ of contributions came from political organizations - the largest share in Washington's 1987 campaign. In the Hogan and Simpson study of a six-month period of fund-raising (January through June 1987), political interests represented only $2 \%$ and ranked seventh among the coalition's partners. We argue that politicians and their organizations (e.g., political action committees, ward organizations) would give money to campaigns early - before the filing deadline in December - to have greater influence on who runs for office. The Hogan and Simpson study may 
have missed some "early" funding by limiting the analysis to the January to June period that follows the filing deadline for candidates. Thus, our larger sample of contributors produced different findings.

Finally, we found significant geographic differences in the sources of contributors to the Daley and Washington campaigns. Washington's support was more strongly from Chicago neighborhoods and non-Illinois contributors. Daley benefited most from Chicago's downtown interests and other Illinois donors. Our findings in this area have a similarity to other research on sources of support and funding for white versus minority candidates for mayor. White, conservative candidates tend to draw more support from downtown interests, whereas minority candidates who seek to overturn the governing regime in the city must often turn to neighborhood interests and out-of-state and national minority interests to establish their campaign's support base (see, e.g., Browning, Marshall, and Tabb 1997; Holli and Green 1989, 81; Kleppner 1985, 147, 155; Pinderhughes 1997). This is another area not examined in the Hogan and Simpson work.

Although both studies employed somewhat different approaches and methods to studying campaign fund-raising coalitions, the overall conclusions are the same. Washington and Daley had distinctive fund-raising coalitions in their mayoral campaigns. We believe that our focus on nonindividual contributors, which were easily classified into interests and groups, permitted us to provide more specificity to the identification of the coalition partners. At the same time, we believe that Hogan and Simpson have made a useful addition to the research by attempting to categorize the individual contributors to these campaigns. In each case, the studies have made a contribution to better understanding of fund-raising coalitions in mayoral campaigns and to the character of the governing regimes that developed from the electoral coalitions of mayors Harold Washington and Richard M. Daley.

\section{REFERENCES}

Browning, R. P., D. R. Marshall, and D. H. Tabb, eds. 1997. Racial politics in American cities. $2 d$ ed. New York: Longman.

Gierzynski, A., P. Kleppner, and J. Lewis. 1996. The price of democracy: Financing Chicago's 1995 city elections. DeKalb: Northern Illinois Univ. Press.

Holli, Melvin G., and Paul M. Green. 1989. Bashing Chicago traditions: Harold Washington's last campaign. Grand Rapids, MI: William B. Eerdmans.

Kleppner, P. 1985. Chicago divided: The making of a black mayor. DeKalb: Northern Illinois Univ. Press.

Krebs, T. B. 1998. The determinants of candidates' vote share and the advantages of incumbency in city council elections. American Journal of Political Science 42:921-35. 
1999. The political and demographic predictors of candidate emergence in city council elections. Urban Affairs Review 35:279-300.

Pinderhughes, D. M. 1997. An examination of Chicago politics for evidence of political incorporation and representation. In Racial politics in American cities, $2 \mathrm{~d}$ ed., edited by R. P. Browning, D. R. Marshall, and D. H. Tabb, 117-35. New York: Longman.

Simpson, D. 2001. Rogues, rebels, and rubber stamps: The politics of the Chicago city council from 1863 to the present. Boulder, $\mathrm{CO}$ : Westview. 


\title{
PROSPECTS FOR REGIONAL GOVERNANCE Lessons from the Miami Abolition Vote
}

\author{
ANNETTE STEINACKER
}

Claremont Graduate University

\begin{abstract}
Circumstances surrounding the 1997 city dissolution vote in Miami were ideal for establishing a metropolitan government, based on arguments from the traditional urban politics literature. Yet it did not happen. How did the issue make it onto the public agenda but fail to be adopted? The author argues that changes in metropolitan governance need to be understood as the outcomes of an agenda-setting process and not solely based on the distribution of winners and losers, as suggested by the public-choice/metropolitan reform literature. The Miami case clearly illustrates the importance of focusing events, a skilled policy entrepreneur, and timing of events as interest fades and the window of opportunity closes. It also illustrates the power of a policy image to trigger emotional attachments that can mobilize inattentive publics.
\end{abstract}

On September 4, 1997, a referendum to disincorporate the city of Miami was held. Dissolution would have had the immediate effect of consolidating the city with the unincorporated territory governed by Metro-Dade County. The county government already had primary service delivery responsibilities for more than half a million people. Consolidation with the city would have added another 350,000 and created a very extensive regional government, similar to that advocated in several contemporary works in urban politics (Orfield 1997; Pierce 1993; Rusk 1993). Based on the traditional urban politics literature, conditions were very favorable for this version of a city-county consolidation to occur, yet it failed. In the past, consolidation efforts were successful in cities where a public service or corruption scandal had occurred, suburban residents could not block the vote, minority political power would not suffer, and local elite groups such as business, union, or media leaders did not oppose the plan (Harrigan 1993). All of these factors held in Miami, making it the most likely case for creation of a new metropolitan government in recent time. Examining reasons for its failure illustrates 